\title{
FLOCCULATION OF FINE FLUORITE PARTICLES WITH CORYNEBACTERIUM XEROSIS AND COMMERCIAL LONG CHAIN POLYMERS
}

\author{
Lisandra N. Rigo; Angela Maria Pinto; Norimar D’Avila Denardin; Ivo André H. Schneider*
}

Faculdade de Engenharia e Arquitetura, FAMV, Universidade de Passo Fundo, Passo Fundo, RS, Brasil

Submitted: January 17, 2002; Returned to authors for corrections: April 08, 2002; Approved: September 24, 2002.

\section{SHORT COMMUNICATION}

\begin{abstract}
This work aimed to study, comparatively, the flocculation of fluorite particles with Corynebacterium xerosis cells and three commercial long chain polymers. Best flocculation results were obtained with cells of $C$. xerosis and with an anionic polyacrylamide. Both were effective in solids removal and water clarification, although flocculation with C. xerosis cells requires a higher dosage of reagent per mass unit of processed ore.
\end{abstract}

Key words: Corynebacterium xerosis, flocculation, fluorite, polymers

Thickening of mineral/water suspensions is a common operation in the mineral processing industry. The efficiency of such gravity settling operations can be substantially increased by aggregation of the mineral particles, which can be carried out with the aid of long chain synthetic flocculants (4). There is a wide range of flocculants available including polyacrylamides, polyethylene oxides, and polyimines $(5,6)$. These vary in chemical, ionic charge, molecular weight, cross-linking branching, and physical form (e.g. emulsion, gel, powder, or bead). The most common polymeric flocculants used in the mineral processing operations are high molecular weight $\left(>10^{6}\right)$ polyacrylamides (1). These reagents are very efficient even when applied in low dosages (7).

In previous papers, it was shown that the bacterium Corynebacterium xerosis is also an excellent flocculant for the minerals fluorite and calcite $(2,3)$. The best cell concentration was determined and the effect of the medium $\mathrm{pH}$ was evaluated and discussed. The mechanism of flocculation was proposed to occur by cell bridging. The cells adhere to the solid surfaces, aggregate the minerals, and improve the settling rates of the particles.

However, the use of microorganisms to flocculate minerals is a new technology and it is necessary to evaluate its competitiveness with common flocculants used in the mining industry. Thus, the aim of this work was to study, comparatively, the efficiency of flocculation of fluorite particles with C. xerosis cells as well as with commercial long chain polyacrylamides.

To carry out the experimental work, fluorite crystals (99\% $\mathrm{CaF}_{2}$ ) were obtained from a mining company (Criciúma - Santa Catarina, Brazil). The crystals were ground in a laboratory mill to particle size below $37 \mathrm{~mm}$ (400\# Tyler).

The bacterium Corynebacterium xerosis, from Caroline Biological Supply Company - USA, was grown for 72 hours in nutrient broth. The bacterium cultures were produced in $300 \mathrm{ml}$ flasks, continuously shaken at $37^{\circ} \mathrm{C}$. Cells were harvested by centrifugation, washed twice in distilled water, and suspended in water to give a $2 \mathrm{~g} / \mathrm{l}$ suspension (dry basis). This stock cell solution was kept at $5^{\circ} \mathrm{C}$ and used in flocculation studies within 24 hours.

The polymeric flocculants included in this study were an anionic polyacrylamide ( $N a l c o ® 9915)$, a cationic polyacrylamide (Nalco® 8589), and a non-ionic polyacrylamide (Nalco® 4032), supplied by "Nalco do Brasil Ltda" as dry powder polyacrylamides of high molecular weight. The polymers were prepared in stock solution concentration of $0.5 \mathrm{~g} / \mathrm{l}$ and all solutions were used within 24 to $48 \mathrm{~h}$ after preparation.

Flocculation studies were carried out using a standard "Jar Test" apparatus. Settling tests were performed with $1000 \mathrm{ml}$ suspensions containing $10 \mathrm{~g} / \mathrm{l}$ of fluorite suspended in distilled water at $\mathrm{pH} 6.0+/-0.5$. The suspensions were stirred for $1 \mathrm{~min}$ at

\footnotetext{
* Corresponding author. Mailing address: Universidade de Passo Fundo, Faculdade de Engenharia e Arquitetura, FAMV, Campus I, Bairro São José. 99001-970, Passo Fundo - RS, Brasil. Tel.: (+5554) 313-8424. Fax: (+5554) 316-8211. E-mail: ivoandre@upf.tche.br
} 
$250 \mathrm{rpm}$ to promote a uniform distribution of the flocculant. The stirrer speed was reduced to $50 \mathrm{rpm}$ for 2 min, to create low shear conditions and allow floc formation. Particles were then allowed to settle under gravity and samples were collected 1 minute after mixing from $10 \mathrm{~cm}$ below the water surface. After this, the medium $\mathrm{pH}$ was measured and the flocculation efficiency was evaluated by the following parameters:

- naked eye and microscope observation of the floc quality;

- residual turbidity in nephelomectric units of turbidity (NTU);

- solids removal from water

The tests with each one of the reagents were conducted with three replications and the results were expressed by the mean $(\mathrm{x})$ and the standard deviation $\left(\sigma_{\mathrm{x}}\right)$.

Table 1 shows the results of flocculation with three long chain polymers and with $C$. xerosis cells. Flocculation was attained with $C$. xerosis cells as well with the anionic and the cationic flocculants. In all these systems, solids removal efficiency was over $96 \%$. However, better flocculation was obtained with $C$. xerosis cells and with the anionic flocculant. It was observed qualitatively by naked eye examination of the floc size and by the residual turbidity of the water. Poor flocculation results were obtained with the non-ionic flocculant.

These results confirm the role of the electrostatic mechanism on adhesion of the bacteria or the flocculant onto mineral particles. At $\mathrm{pH} 7.0$, the fluorite has a high positive charge (about $+60 \mathrm{mV}$ ) and the best flocculation results were attained with the negative bacteria (about $-30 \mathrm{mV}$ ) (2) or the negative charged flocculant.

Although flocculation with the anionic polyacrylamide was similar in solids removal and residual turbidity to that provided by C. xerosis cells, some important differences were observed. $C$. xerosis cells provide larger flocs and higher settling rates. However, the residual turbidity is more variable (see standard deviation results). Bacteria cells not attached to the flocs remain in the water and sometimes it is difficult to determine the best dosage and stirring speed to achieve optimum flocculation and minimum residual turbidity. The results associated with flocculation by the anionic polymer are less sensitive to mechanical and dosage variables.

The dosage of $C$. xerosis cells required to flocculate fine fluorite suspensions is higher than that of long synthetic polymers. Flocculation with $C$. xerosis cells needs about $40 \mathrm{mg}$ / 1 (or $4 \mathrm{~kg} / \mathrm{t}$ ). Long chain polyacrylamides flocculates the same suspension at concentrations in the range of 2 to $20 \mathrm{mg} / \mathrm{l}$ (or 0.2 to $2 \mathrm{~kg} / \mathrm{t}$ ). However, microorganisms can be potentially produced at a lower cost than most of the commercial synthetic flocculants.

Microorganisms are potential low cost flocculants for solidliquid operations in mineral processing. Further studies concerning the production on large scale of $C$. xerosis are necessary to investigate its competitiveness, and this is now the subject of our current research.

\section{RESUMO}

\section{Floculação de partículas de fluorita com Corynebacterium xerosis e com polímeros de cadeia longa comerciais}

O objetivo do presente trabalho foi estudar, comparativamente, a floculação de partículas de fluorita com células da bactéria Corynebacterium xerosis e com três polímeros floculantes comerciais. Os melhores resultados foram obtidos com C. xerosis e com uma poliacrilamida aniônica. Ambos sistemas são eficientes em termos da remoção de sólidos e na clarificação da água, porém a floculação com $C$. xerosis requer uma dosagem mais elevada de reagente por unidade de massa de minério processado.

Palavras-chave: Corynebacterium xerosis, floculação, fluorita, polímeros.

\section{ACKNOWLEDGEMENTS}

The authors wish to acknowledge the financial support provided by the following Brazilian institutions: FAPERGS (process 96/1789.5), CNPq (process 511968/96-8), and CNPqPADCT (62.0185/98-8).

\section{REFERENCES}

1. Besra, L.; Sengupta, D.K.; Roy, K. Flocculant and surfactant aided dewatering of fine particle suspensions: a review. Min. Pro. Ext. Met. Rev., 18: 67-103, 1998.

2. Haas, S.R.; Nascimento, F.R.; Schneider, I.A.H.; Gaylarde, C. Flocculation of fine fluorite particles with Corynebacterium xerosis Rev. Microbiol., 30: 225-230, 1999.

3. Haas, S.R.; Nascimento, F.R.; Schneider, I.A.H. Flocculation of fine calcite particles with Corynebacterium xerosis. XXI International Mineral Processing Congress, Rome, 2000, V.A.; p.57-61.

4. Hogg R. Flocculation and dewatering. Int. J. Miner. Process., 58: 223-236, 2000.

5. Kitchener, J.A. Flocculation in mineral processing. In: Ives, K.J. (ed.) The scientific basis of flocculation. Alphen aan den Rijn, Netherlands, 1978, p.283-328.

6. Smith, R.W. Liquid and solid wastes from mineral processing plants. Min. Pro. Extr. Met. Rev., 16: 1-22, 1996.

7. Somasundaran, P. Principles of flocculation, dispersion, and selective flocculation. In: Somasundaran, P. (ed.). Fine particle processing. New York, AIME, 1980, p.947-976. 